Brit. J. vener. Dis. (1961), 37, 247.

\title{
CORTISONE IN THE PREVENTION OF THE HERXHEIMER REACTION IN EARLY SYPHILIS*
}

\author{
BY \\ P. DE GRACIANSKY AND C. GRUPPER \\ Hôpital Saint-Louis, Paris
}

WITH THE ASSISTANCE (FOR STATISTICS) OF

F. BODIN AND J. SAUGIER

Since 1951, at our clinic, where rapid treatment of all stages of syphilis is undertaken by a single course of penicillin, we have systematically studied the help which cortisone can give in tackling the problems produced by this treatment. The results obtained by this method have been described in several publications (Graciansky, Voisin, Grupper, and Landrieux, 1951; Graciansky, Grupper, Lefort, and Grenier, 1952; Graciansky, Grupper, Lefort, and Bouchard, 1951; Graciansky and Grupper, 1953, 1957; Graciansky, Grupper, Leclercq, and Massias, 1953; Graciansky, Poligny, and Peras, 1953; Grupper, 1953), and especially in the theses of Cornu (1956) and Valory (1959). From the early days of massive and rapid penicillin therapy, cortisone has seemed to us to be an especially useful adjuvant. The antiphlogistic, anti-inflammatory, and antithermal actions attributed to it by physiologists and pharmacologists led us to study its value in preventing or reducing the Herxheimer reaction.

However, a review of the literature did not encourage such an experiment. Sheldon, Heyman, and Evans (1952) and Heyman, Sheldon, and Evans (1952), studying the action of ACTH on the Herxheimer reaction in the rabbit, observed an increase in the number of treponemes in the lesions under the influence of ACTH (a fact already reported by Turner and Hollander (1950) and by De Lamater, Saurino, and Urbach (1952); they also found that this form of corticotherapy did not prevent the massive invasion of the syphilitic lesions by sheets of polymorphonuclear leucocytes after the administration of penicillin, an invasion which, according to them, characterizes the Herxheimer reaction.

More recently, Musumeci (1960) reported a reduction in the perivascular cellular infiltration with predominance of histiocytes and lymphocytes

* Paper read at the meeting of the M.S.S.V.D. in Paris on May 12, and an increase in the amorphous basal substance.

Clinical experiments carried out during the past 10 years have confirmed our hopes of preventing a Herxheimer reaction and have demonstrated the anti-inflammatory action of cortisone on all the clinical and biological manifestations of all stages of syphilis.

The Herxheimer reaction which was known to follow the use of traditional antisyphilitic remedies, such as mercury, arsenic, and bismuth, was observed immediately after the introduction of penicillin in the treatment of syphilis (Mahoney, Arnold, and Harris, 1943). In early syphilis it is less frequent with penicillin than with arsenic and bismuth, but has more dramatic effects on the temperature. The incidence has been variously reported as follows:

Leifer (1946), 85 per cent.; Midana (cited by Garnier, 1961), 80 per cent.; Farmer (1948), 41 per cent.; Degos and Garnier (1949), 62 per cent.; Owsínska and Wasilewska (1959), $55 \cdot 3$ per cent.; and Garniert (1961), only $31 \cdot 8$ per cent.

In considering these figures, we must bear in mind, as we shall see later, the different preparations of penicillin, certain types (crystalline penicillin; $\mathrm{NN}^{\prime}$-dibenzyl-ethylene-diamine-bipenicillin G) being, in our experience, more likely to provoke febrile reactions than others.

On the other hand, the Herxheimer reaction is more frequent in late visceral syphilis, and especially in neurosyphilis and general paralysis, with penicillin than with metal therapy, reaching an incidence of 50 to 80 per cent. In patients without clinical signs of neurosyphilis but with changes in the cerebrospinal fluid, a Herxheimer reaction may often be severe and sometimes fatal (Scott, Maxwell, and Skinner, 1949).

t In fact, the figure given by this author represents the overall percentage: there was a frequency of 43 per cent. in primary syphilis and 41.6 per cent. in secondary syphilis, but of only $12 \cdot 2$ per cent. in latent syphilis. 
In aortic syphilis, the therapeutic paradox may arise from the too rapid healing of gummata.

In congenital syphilis the reaction is more frequent and serious with penicillin therapy than with other methods and has produced a higher mortality rate than the treponemal infection itself.

The gravity and frequency of the Herxheimer reaction have led many to the use of preventive therapy. Joulia and Pautrisel advised anti-histamines, and Bolgert advised a course of injections of mercury cyanide before the penicillin; the latter should then be started with small doses and gradually increased. Other authors advise homeopathic doses of penicillin before the massive doses (Debré, 1949) or the use of another antisyphilitic drug such as bismuth.

For 10 years, in this clinic, we have recommended the routine use of corticotherapy, a method of prevention which has now been adopted, not only by dermatologists and syphilologists, but also by general physicians, neurologists, and cardiologists. The present communication describes our experience in the prevention of the Herxheimer reaction in early syphilis.

\section{Material and Methods}

(1) Choice of Patients.-More than 650 patients have been treated for syphilis in our department during the past 10 years, but the temperature charts were available for only 307 cases of early syphilis and 71 of late syphilis (a total of 378).

The 307 cases of early syphilis comprised 33 seronegative primary syphilis, 128 sero-positive primary syphilis, and 146 florid secondary syphilis.

The 71 cases of late syphilis comprised 29 visceral tertiary syphilis, 37 late latent syphilis, and five late congenital syphilis. (The number of patients in the last category is too small for valid conclusions to be drawn).

Of the 378 patients, 254 ( 224 of early syphilis and thirty of late syphilis) received preventive steroid therapy, and 124 (83 of early syphilis and 41 of late syphilis) received penicillin only and thus served as controls.

(2) Characteristics of the Herxheimer Reaction.-In assessing the reaction, we considered only the thermal response. The patient's temperature was taken every hour for 24 hours, and sometimes for $\mathbf{3 6}$ hours, after the penicillin injection. Our experience confirmed that of other authors (Tzanck); although the febrile peaks usually occur between 6 and 12 hours, they may be delayed until 20 to 30 hours in a few cases.

When the penicillin therapy was given in a series of several injections, the temperature was recorded hourly after the second and third injections. Unlike other authors, we have sometimes observed repeated febrile reactions to penicillin identical with those described by Milian following arsenic therapy.

When the Herxheimer reaction was severe, it was always associated with muscular and joint pains, malaise, nausea, and especially headache.

The reactivation or enlargement of pre-existing primary or secondary lesions was rarely observed and was usually too subjective for assessment.

(3) Penicillin Dosage.-The type of penicillin varied over the years, as improved preparations became available.

(a) 35 patients received penicillin quininate (péniquinyl, Roussel: microcrystals of benzyl-penicillinate of vinylquinuclidyl-méthoxy-quinolyl-carbinol in oil) containing 150,000 units per ml., three injections of 3 million units at 5-day intervals.

(b) 47 patients received P.A.M. or Flocilline (procaine penicillin with 2 per cent. aluminium monostearate), three injections of 3 million units at weekly intervals.

(c) 199 patients received either Benzathine penicillin ( $\mathrm{NN}^{\prime}$-dibenzyl-ethylene-diamine-bipenicillin G) marketed in France as Extencilline or Panbiotic Bristol, a mixture of penicillin $\mathrm{G}$. procaine penicillin $\mathrm{G}$, and $\mathrm{NN}^{\prime}$ dibenzy]-ethylene-diamine-bipenicillin $G$ (marketed in France as Extencillin Bipenicillin). These were given as a single injection of 2.4 mega units.

(4) Technique of Steroid Therapy.-Of the 307 cases of early syphilis, 224 received preventive steroid therapy as follows:

(a) 44 patients received a dose of 100 to $300 \mathrm{mg}$. oral cortisone daily for 1 to 10 days preceding or overlapping the injection of penicillin.

(b) Eleven patients received from 100 to $200 \mathrm{mg}$. oral hydrocortisone (17-hydroxycorticosterone) daily for 4 to 6 days.

(c) 100 patients received 30 to $50 \mathrm{mg}$. oral Cortancyl (delta-dehydrocorticosterone) daily for 5 to 6 days.

(d) 29 patients were given oral delta 1 -dehydrocorticosterone, and in addition a preparation of injectable cortisone was given in the same syringe as the therapeutic injection of penicillin: in 24 patients we added $1-3 \mathrm{ml}$. of a suspension of 17-hydroxycorticosterone acetate and in five patients we added 1 to $3 \mathrm{ml}$. of a solution of $\mathrm{d}^{\prime}$ Hexadecadrol.

(e) During the past 2 years, to simplify this preventive steroid therapy, which at first lasted for at least 3 to 5 days before the therapeutic injection of penicillin, we 
reduced the preventive dosage in 24 patients to one injection of steroid added to the therapeutic injection of penicillin.

Under this scheme nine patients received 1 to $3 \mathrm{ml}$. 17-hydroxycorticosterone and fifteen received $1 \cdot 5$ to $3 \mathrm{ml}$. dexamethasone.

The latter preparation is that at present in regular use.

\section{Results and Discussion}

Fig. 1 and Table I show the percentage of febrile reactions observed after the first injection of penicillin. Only those cases who had a temperature of $38^{\circ} \mathrm{C}$. or above were considered to have a febrile Herxheimer reaction:

(1) Contrary to common opinion, the Herxheimer

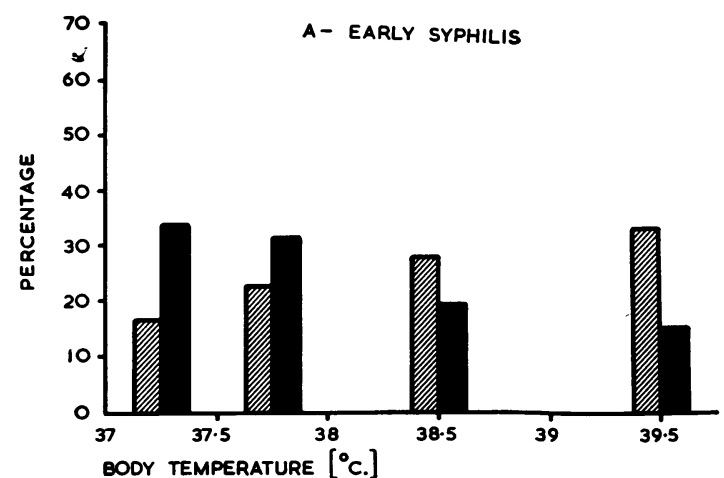

FIG. 1.-Effects of preventive steroid therapy on incidence of febrile reactions (above $38^{\circ} \mathrm{C}$.) in early and late syphilis treated with penicillin.

TABLE I

378 CASES OF SYPHILIS TREATED WITH PENICILLIN, WITH AND WITHOUT ASSOCIATED STEROID THERAPY, 1951-61

\begin{tabular}{|c|c|c|c|c|c|c|c|c|c|c|c|c|c|c|}
\hline & & & & \multicolumn{5}{|c|}{ With Preventive Steroid Therapy } & \multicolumn{5}{|c|}{ Without Preventive Steroid Therapy } & \multirow{3}{*}{ Total } \\
\hline \multirow{2}{*}{\multicolumn{4}{|c|}{ Type of Syphilis }} & \multicolumn{2}{|c|}{$\leqslant 38^{\circ}$} & \multicolumn{2}{|c|}{$>38^{\circ}$} & \multirow{2}{*}{ Total } & \multicolumn{2}{|c|}{$\leqslant 38^{\circ}$} & \multicolumn{2}{|c|}{$>38^{\circ}$} & \multirow{2}{*}{ Total } & \\
\hline & & & & No. & $\begin{array}{c}\text { Per } \\
\text { cent. }\end{array}$ & No. & $\begin{array}{l}\text { Per } \\
\text { cent. }\end{array}$ & & No. & $\begin{array}{c}\text { Per } \\
\text { cent. }\end{array}$ & No. & $\begin{array}{l}\text { Per } \\
\text { cent. }\end{array}$ & & \\
\hline \multirow{2}{*}{ Primary } & Sero-ne & ative & .. & 13 & $61 \cdot 9$ & 8 & $38 \cdot 1$ & 21 & 5 & $41 \cdot 6$ & 7 & $58 \cdot 4$ & 12 & 33 \\
\hline & Sero-pc & itive & . & 65 & $69 \cdot 9$ & 28 & $30 \cdot 1$ & 93 & 10 & $28 \cdot 5$ & 25 & $71 \cdot 5$ & 35 & 128 \\
\hline \multicolumn{3}{|l|}{ Secondary } & . & 75 & $68 \cdot 2$ & 35 & $31 \cdot 8$ & 110 & 17 & $47 \cdot 3$ & 19 & $52 \cdot 7$ & 36 & 146 \\
\hline \multicolumn{3}{|c|}{ Total Early Syphilis } & $\ldots$ & 153 & $68 \cdot 4$ & 71 & $31 \cdot 6$ & 224 & 32 & $38 \cdot 6$ & 51 & $61 \cdot 4$ & 83 & 307 \\
\hline \multicolumn{3}{|l|}{ Tertiary } & $\ldots$ & 11 & $68 \cdot 2$ & 3 & $31 \cdot 8$ & 14 & 11 & $73 \cdot 3$ & 4 & $26 \cdot 7$ & 15 & 29 \\
\hline \multicolumn{3}{|c|}{ Latent $\quad .}$. & $\ldots$ & 15 & 100 & 0 & & 15 & 20 & $90 \cdot 8$ & 2 & $9 \cdot 2$ & 22 & 37 \\
\hline \multicolumn{4}{|c|}{ Late Congenital } & 1 & 100 & 0 & & 1 & 4 & & 0 & & 4 & 5 \\
\hline \multicolumn{2}{|c|}{ Total Late Syphilis } & . & . & 27 & 90 & 3 & 10 & 30 & 35 & $85 \cdot 4$ & 6 & $14 \cdot 6$ & 41 & 71 \\
\hline Total & $\ldots$ & . & $\ldots$ & 180 & $70 \cdot 8$ & 74 & $29 \cdot 2$ & $\begin{array}{c}254 \\
67 \cdot 2 \%\end{array}$ & 67 & 54 & 57 & 46 & $\begin{array}{c}124 \\
32 \cdot 8 \%\end{array}$ & 378 \\
\hline
\end{tabular}

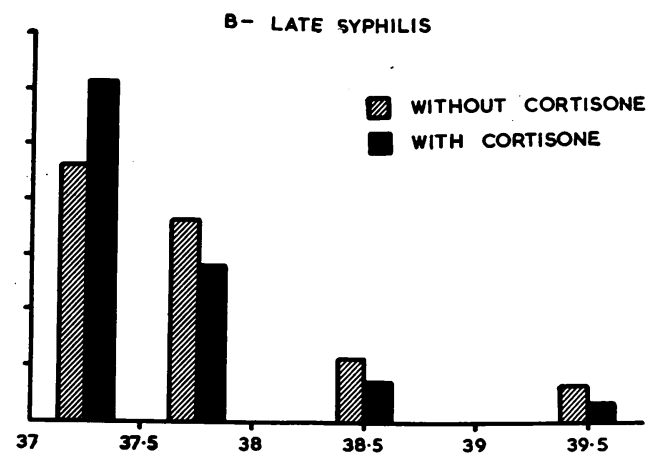

reaction after penicillin therapy was more frequent in early syphilis (61.4 per cent.) than in late syphilis (14.6 per cent.), but the number of patients in this second group was small.

(2) In patients with early syphilis who received preventive cortisone therapy, the percentage of febrile reactions ( 31.6 per cent.) was less than in the controls (61.4 per cent.) who received penicillin alone.

(3) In patients who received steroid therapy and nevertheless had a Herxheimer reaction, the fever was less severe (between $38^{\circ}$ and $39^{\circ} \mathrm{C}$.) than in the controls (all above $39^{\circ} \mathrm{C}$.). 
Influence of the Type of Penicillin on the Herxheimer Reaction

Fig. 2 and Table II show that certain types of penicillin were more pyrogenic than others. In patients who did not receive steroid therapy, P.A.M. appeared to be less pyrogenic than Peniquinyl, Extencilline, and Extencillin-Bipenicillin. The latter preparation was unequivocally the most pyrogenic (65.5 per cent. against 61.4 per cent., the average of the total positive Herxheimer reactions). This observation has also been noted in our dermatological practice, e.g. in the treatment of lichen planus or psoriasis (Flandin). Associated steroid therapy diminishes this pyrogenic action of Extencillin by only a slight amount.

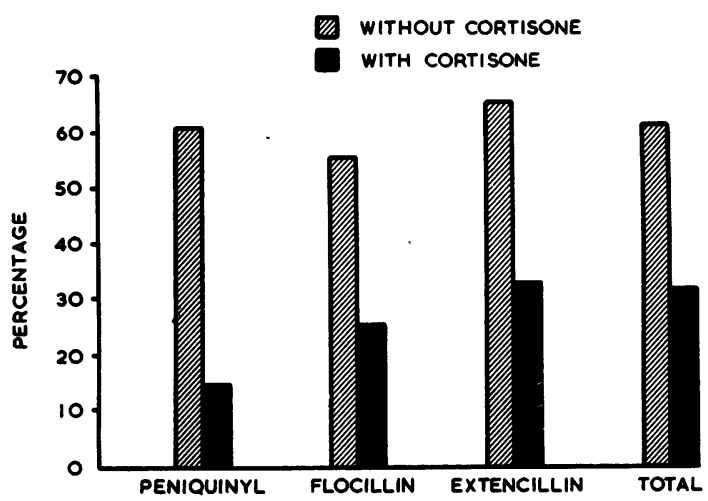

FIG. 2.-Febrile reactions (above $38^{\circ} \mathrm{C}$.) in early syphilis treated with various preparations of penicillin.

Influence of the Type of Preventive Steroid Therapy on the Herxheimer Reaction

Table III gives a general picture of the results obtained with different preparations of steroids.

(1) The original technique, whereby oral cortisone
TABLE III FEBRILE REACTIONS IN 224 CASES OF EARLY SYPHILIS
GIVEN VARIOUS SCHEDULES OF PREVENTIVE STEROID THERAPY AND IN 83 CONTROLS

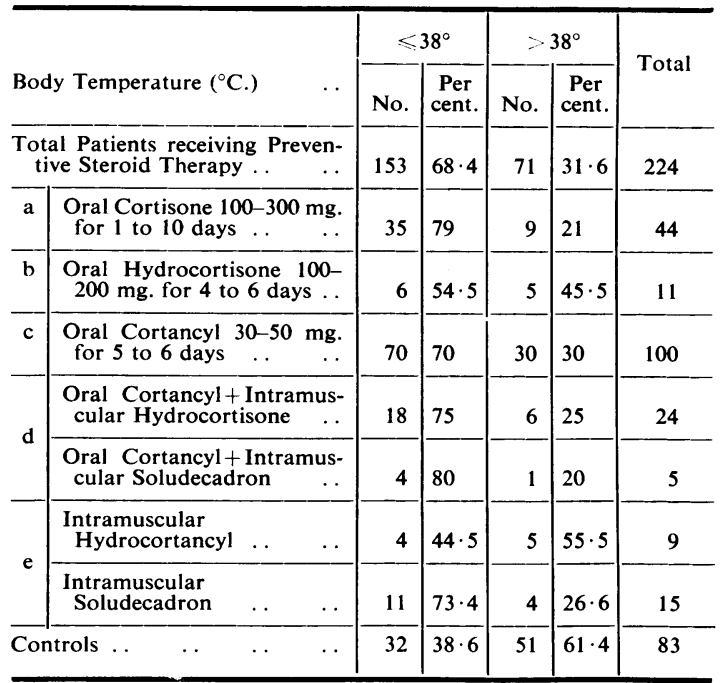

was given before or overlapping the injection of penicillin, was undoubtedly the most efficacious: 21 per cent. of positive Herxheimer reactions against the average of 31.6 per cent, for all the patients receiving steroid therapy, and 61.4 per cent. for the controls who did not receive steroid therapy.

(2) The current technique, which is much more simple, whereby 1.5 to $3 \mathrm{ml}$. dexamethasone is added to the single therapeutic injection of penicillin, gives very satisfactory protection. 26 per cent. had Herxheimer reactions against the average of $31.6 \mathrm{per}$ cent. for all the patients receiving steroid therapy and $61 \cdot 4$ per cent. for the controls who did not receive associated steroid therapy.

TABLE II

FEBRILE REACTIONS IN 224 CASES OF EARLY SYPHILIS GIVEN VARIOUS PREPARATIONS OF PENICILLIN WITH PREVENTIVE STEROID THERAPY AND IN 83 CONTROLS

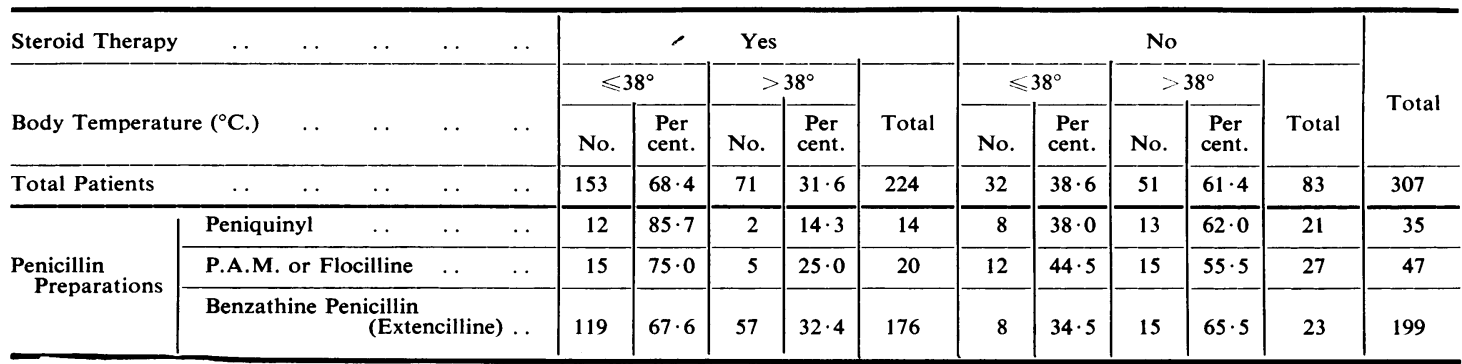




\section{Summary and Conclusions}

(1) The Herxheimer reaction, defined as a rise in temperature above $38^{\circ} \mathrm{C}$, , was found to be more frequent in early $(61.4$ per cent.) than in late syphilis $(14.6$ per cent.)

(2) The administration of steroid therapy in association with rapid penicillin therapy has given a regular quantitative and qualitative reduction in the number of febrile Herxheimer reactions in early syphilis.

(3) Comparison of the different preparations of penicillin and the different steroids used showed that certain types of penicillin were more pyrogenic than others (especially $\mathrm{NN}^{\prime}$ dibenzyl-ethylene-diaminebipenicillin G) and that certain steroids (such as dexamethasone mixed with the single injection of penicillin, which is the technique we are currently using) give very satisfactory protection against the Herxheimer reaction.

\section{REFERENCES}

Cornu, J. (1956). Thèse, Paris.

Debré, R. (1949). Sem. Hôp. Paris, 25, 357.

Degos, R., and Garnier, G. (1949). Cited by Garnier (1961).

De Lamater, E. D., Saurino, V. R., and Urbach, F. (1952). Amer.J. Syph., 36, 127.

Farmer, T. W. (1948). J. Amer. med. Ass., 138, 480.

Garnier, G. (1961). Bull. Soc. Franç. Derm. Syph., 68, 206.

Graciansky, P. de, and Grupper, C. (1953). "Proc. X int. Congr. Derm., London, 1952”, p. 175. B.M.A., London.

- (1957). Rev. franç. Ét. clin. biol., 2, 579

- _ Leclercq, R , and Massias, P. (1953). Bull. Soc. franc. Derm. Syph., 60, 128. ,$- \frac{}{510}$. Lefort, P., and Bouchard, R. (1951). Ibid., 58,

$\longrightarrow, \frac{5}{-}$, and Grenier, B. (1952). Ibid., 59, 97.

-, Poligny, O., and Peras, H. (1953). Ann. med. Psychiat., 5, 646.

- Voisin, J., Grupper, C., and Landrieux, P. (1951). Bull. Soc. franc. Derm. Syph., 58, 574.

Grupper, C. (1953). Ibid., 60, 474.
Heyman, A., Sheldon, W. H., and Evans, L. D. (1952) Brit. J. vener. Dis., 28, 50.

Leifer (1946). Cited by Garnier (1961).

Mahoney, J. F., Arnold, R. C., and Harris, A.. (1943). Cited by Garnier (1961).

Midana. Cited by Garnier (1961).

Musumeci, V. (1960). Minerva Derm. (Torino), 35, 12.

Owsinska, I., and Wasilewska, H. (1959). Przegl. Derm. Wener., 46, p. 363. See "Current Literature on Venereal Disease” (1960), p. 43. U.S. Public Health Service, Washington.

Scott, V., Maxwell, R. W., and Skinner, J. S. (1949). J. Amer. med. Ass., 139, 217.

Sheldon, W. H., Heyman, A., and Evans, L. D. (1952). Amer. J. Syph., 36, 77.

Turner, T. B., and Hollander, D. H. (1950). Bull. Johns Hopk. Hosp., 87, 505.

Valory, C. (1959). Thèse, Paris.

La corticothérapie dans la prévention de la réaction de Herxheimer dans la syphilis récente

\section{RÉSUMÉ}

(1) D'après notre statistique, la réaction de Herxheimer, définie par une ascension de la température au-dessus de $38^{\circ} \mathrm{C}$., est plus fréquente au cours de la syphilis récente qu'au cours de la syphilis ancienne: 61,4 contre $14,6 \%$.

(2) Une étude, poursuivie pendant 10 ans, et consistant en l'administration d'une corticothérapie associée systématiquement à la pénicillinothérapie en cure rapide, nous a permis d'obtenir régulièrement, au cours de la syphilis récente, une réduction quantitative et qualitative de la réaction de Herxheimer fébrile.

(3) La comparaison des différentes pénicillines et corticoïdes utilisés nous a permis de reconnaître que certaines préparations de pénicilline sont plus pyrétogènes que d'autres (notamment le $\mathrm{NN}^{\prime}$ dibenzyl-ethylenediamine-bipénicilline $\mathrm{G})$, et que certains corticoïdes, tels que la Déxaméthasone associée à l'injection unique de pénicilline, technique que nous pratiquons actuellement, confèrent une protection très satisfaisante contre la réaction de Herxheimer.

Cette technique permet de réaliser simultanément un véritable traitement prophylactique de l'anaphylaxie à la pénicilline et une prévention efficace de la réaction de Herxheimer. 